\title{
Foreign direct investment, unionised labour markets and welfare*
}

\author{
Jiyun Cao \\ The School of Economics, Nankai University, and Collaborative Innovation Center for China \\ Economy, Tianjin, China \\ and \\ Arijit Mukherjee \\ Nottingham University Business School, UK, CESifo, Germany, INFER, Germany, and GRU, \\ City University of Hong Kong, Hong Kong
}

Submission: November 2017

Accepted: April 20, 2018

\begin{abstract}
Although empirical evidence on the relationship between labour union and foreign direct investment (FDI) is mixed, the theoretical literature mainly explains the negative relationship between labour union and FDI. We show that a multinational firm may prefer FDI in the presence of labour unions if it is sufficiently technologically superior to its domestic counterpart. FDI (compared to export) makes the domestic labour union better off but it makes the consumers, the domestic firm, the foreign labour union and the foreign country worse off, and may reduce domestic welfare. We show the implications of industry-wide and firm-specific labour unions.
\end{abstract}

Key words: Foreign direct investment; Labour union; Welfare

JEL Classifications: F23; J51

Correspondence to: Arijit Mukherjee, Nottingham University Business School, Jubilee Campus, Wollaton Road, Nottingham, NG8 1BB, UK.

Email: arijit.mukherjee@nottingham.ac.uk; Fax: +44 (0)115 8466667

\footnotetext{
* We thank two anonymous referees of this journal, the participants of the "Hitotsubashi Conference on International Trade \& FDI 2013", at Hitotsubashi University, Japan, and especially, Richard Baldwin, the participants of the "2014 International workshop on Corporatization, Privatization, and Internationalization", at the National University of Kaohsiung, Taiwan, the seminar participants at the Bournemouth University, UK, and Swansea University, UK, and the participants of the $17^{\text {th }}$ INFER Annual Conference, 2015, at the University of Bedfordshire, UK, for helpful comments and suggestions. Jiyun Cao acknowledges the financial supports from The Project Sponsored by the Scientific Research Foundation for the Returned Overseas Chinese Scholars, State Education Ministry in 2015, the Fundamental Research Fund for the Central University, and the Humanities and Social Sciences Planning Fund from Chinese Ministry of Education (Grant No. 10YJA790008). The usual disclaimer applies.
} 


\section{Foreign direct investment, unionised labour markets and welfare}

\section{Introduction}

This paper provides a new rationale for undertaking foreign direct investment (FDI), which dominates international trade in recent years (UNCTAD, 2006) and has generated a vast theoretical and empirical literature. ${ }^{1}$ We show that labour market imperfection due to the presence of labour unions may create the incentive for FDI.

The evidence showing the relationship between labour union and FDI is mixed. While Cooke (1997) and Cooke and Noble (1998) show a negative relationship between high labour union density and FDIs by US multinationals, Traxler and Woitech (2000) show that the level of labour union density can have a positive influence on the investments by US multinationals. Coughlin et al. (1991) and Friedman et al. (1992) also show a positive relationship between the degree of labour union and FDI. While the theoretical papers by Naylor (2003) and Naylor and Santoni (2003) explain the negative relationship between labour union and FDI, the theoretical literature did not pay much attention to explain their positive relationship. Our paper fills this gap and provides an explanation for the positive relationship between labour union and FDI.

Using an international duopoly with a foreign firm and a domestic firm, competing in the domestic country, we show that raising rival's $\operatorname{cost}^{2}$ may create the motive for undertaking FDI in the presence of unionised labour markets. While FDI may increase the foreign firm's wage, it also increases the wage for its domestic counterpart. If labour productivity of the foreign firm is sufficiently higher than that of the domestic firm, the burden of a higher wage following FDI is significantly more on the domestic firm than on the foreign firm, thus making the foreign firm better off under FDI compared to export.

\footnotetext{
${ }^{1}$ See, Saggi (2002) for a recent survey on FDI.

${ }^{2}$ See Salop and Scheffman $(1983,1987)$ for popularising the raising rival's cost theory in the industrial organisation literature
} 
We also show that if the motive for FDI is to raise the rival's cost, FDI creates striking implications on the consumers and social welfare. FDI (compared to export) reduces consumer surplus and foreign welfare, and it reduces domestic welfare if the foreign firm is sufficiently technologically superior compared to the domestic firm. FDI also makes the domestic firm and the foreign labour union worse off but it makes the domestic labour union better off compared to export. A higher labour demand in the domestic country and a lower labour demand in the foreign country under FDI compared to export are the reasons for these results. Thus, our paper shows a concern to the common wisdom suggesting that FDI benefits consumers by increasing competition in the product market.

It follows from our analysis that an industry-wide labour union in the domestic country charging a uniform wage may create higher incentive for FDI and domestic welfare compared to both the industry-wide domestic labour union charging discriminatory wages ${ }^{3}$ and firmspecific domestic labour unions.

One remark is in order at this point. Although we show that the labour market imperfection due to the presence of labour unions may create the raising rival's cost motive for FDI, one may imagine that, in the presence of significant firm-heterogeneity, a similar effect may arise even if there is no labour union but a tight labour market (or a tight market for the specific factors used by the multinational and the host-country firms) in the domestic country increases wage (or the factor price) under FDI compared to export by the multinational firm. In other words, even if there is no labour union but production requires certain specialised workers which are scarce in supply, the raising rival's cost motive for FDI remains in the presence of significant firm-heterogeneity. Hence, the basic message of this paper, i.e., a multinational firm that is significantly productive compared to the host-country firms may benefit from FDI

\footnotetext{
${ }^{3}$ This result is in contrast to the usual belief that an upstream agent prefers discriminatory pricing compared to a uniform pricing if the downstream agents are asymmetric (Yoshida, 2000). We show that this usual conclusion may not hold if the upstream pricing strategy affects the downstream agent's production strategy.
} 
compared to export by increasing the demand and the price of certain key factors of production, has a broader appeal than the model considered in this paper.

The remainder of the paper is organised as follows. We review the literature in Section 2. Section 3 describes the model and derives the results. Section 4 concludes.

\section{Literature review}

Our paper contributes to the literature determining the factors for inward greenfield FDI. The factors which are responsible for creating the incentive for inward FDIs in the existing literature are trade cost saving and lower cost of production (Brainard, 1997, Markusen, 1998), informational problem (Horstmann and Markusen, 1987 and 1996, Bagwell and Staiger, 2003 and Moner-Colonques et al., 2008), asset-seeking, social and cultural factors (Galan et al., 2007), exchange rate uncertainty (Aray and Gardeazabal, 2010) and environment regulation (Dijkstra et al., 2011). In contrast, we show the role of the unionised labour market in creating the incentive for FDI. Thus, our paper provides a new rationale for undertaking FDIs.

Considering a "right-to-manage" model of labour union, we show that the raising rival's cost motive can be the incentive for FDI. Thus, our paper provides a reason for FDI that is different from Bughin and Vannini (1995), Zhao (1995), Lommerud et al. (2003), Mukherjee (2008) and Mukherjee and Suetrong (2012), which considered FDIs in unionised labour markets.

In an integrated market with an "efficient bargaining model" of labour union, Zhao (1995) shows that a multinational firm prefers to use two plants in two countries rather than using only one plant in its home country. Thus, Zhao (1995) shows that, in the presence of labour unions, diversifying productions in the domestic and foreign plants may help to reduce the loss from

\footnotetext{
${ }^{4}$ The efficient bargaining model of labour union, which stipulates that firms and unions bargain over wages and employment, is an alternative to the right-to-manage model of labour union, where the firms and the union bargain over wages and the firms hire workers according to their choice. See, Layard et al. (1991) for arguments in favour of the right-to-manage model.
} 
strike, thus creating the incentive for FDI. In contrast, like many other papers (Bughin and Vannini, 1995, Lommerud et al., 2003, Mukherjee, 2008 and Mukherjee and Suetrong, 2012), significant plant specific costs induce the multinational firm to use only one plant in our analysis. The multinational firm either exports from the foreign plant or produces under FDI in the domestic plant, and FDI occurs due to the raising rival's cost motive. In different contexts, Bughin and Vannini (1995), Lommerud et al. (2003), Mukherjee (2008) and Mukherjee and Suetrong (2012) also consider FDIs in unionised labour markets. However, the reasons for FDIs in those papers are due to the lower costs of production in the host country of the multinational firm, which is different from our reason.

In a closed economy with symmetric firms, Vannini and Bughin (2000) show that the raising rival's cost cannot be an equilibrium strategy under the "right-to-manage" model, where the unions and firms bargain over wages and the firms hire workers according to their requirements, but it can be the equilibrium strategy under "efficient bargaining" model, where the firms and unions bargain over both wage and employment. ${ }^{5}$ In contrast, we focus on an open economy with strategic FDI and show that the raising rival's cost can be an equilibrium strategy under the right-to-manage model.

In a recent paper, Haufler and Mittermaier (2011) show that there is a positive relationship between labour union and "export-platform FDI" in the presence of strategic tax competition among the host-countries. However, in their paper, the relationship between labour union and FDI is negative under a given tax rate. Hence, our paper differs in two important aspects from Haufler and Mittermaier (2011). First, unlike them, we do not consider "export-platform FDI". Second, and more importantly, we explain the positive relationship between labour union and FDI in the absence of any tax competition. ${ }^{6}$

\footnotetext{
${ }^{5}$ See, Layard et al. (1991) for arguments in favour of the right-to-manage model.

${ }^{6}$ It is often considered that tax competition among the countries results in a waste of resources. Moreover, tax/subsidy policies are not necessarily 'time consistent', implying that governments may deviate from their
} 
Our paper also contributes to the literature examining the welfare effects of an industrywide union and firm-specific unions. Considering industry-wide and firm-specific unionisation, Leahy and Montagna (2000) show that the host-country welfare is higher under firm-specific unions than under an industry-wide union if the firms compete in the hostcountry. We show that this may not be the case when wages are determined under both export and FDI by the foreign firm and raising rival's cost is the motive for FDI. It is important to note that, Leahy and Montagna (2000) consider that if the foreign firm does not undertake FDI to the concerned host-country, it earns an exogenously given profit by locating elsewhere, thus ignoring the endogenous export/FDI choice of the foreign firm, which we consider here. Thus, they fail to explain the role of labour union in attracting FDI.

Finally, our paper can be related to the recent literature on productivity and FDI. Head and Ries (2003) and Helpman et al. (2004) show how productivities of the foreign firms affect the incentives for FDIs. In contrast, the productivity difference between the domestic and the foreign firms plays an important role in our analysis.

\section{The model and the results}

Assume that there are two countries, called foreign and domestic. There is a firm in each country. The foreign firm is called firm 1 and the domestic firm is called firm 2 . The firms compete in the domestic country with homogeneous products. Firm 1 can serve the domestic country either through export or through FDI. We assume that production requires only workers and the firms differ in technologies. Assume that firm 1 requires $\lambda(0<\lambda<1)$ workers to produce one unit of output and firm 2 requires one labour to produce one unit of output.

announced policies (Staiger and Tabellini, 1987, Neary and Leahy, 2000), thus reducing the incentive for using tax/ subsidy in attracting FDI. There has been talk in the USA to end the bidding wars by banning subsidies, the Investment in Britain Bureau has set guidelines in the UK that regional agencies need to respect when offering financial assistance to foreign firms (Fumagalli, 2003). 
Assume that the workers are immobile between countries. The labour market in each country is unionised and the reservation wage of labour is $z$, which is assumed to be zero, for simplicity. The utility of each labour union is $U=w L$, where $w$ is wage and $L$ is the number of workers employed. To show the effects of the labour unions in the simplest way, we assume that each labour union has full bargaining power to determine wage. We consider a right-tomanage model of labour union where the unions determine wages and the firms hire workers according to their requirements.

If firm 1 exports to the domestic country, firms 1 and 2 hire workers from the labour unions in countries 1 and 2 respectively. However, if firm 1 undertakes FDI, both firms hire workers from a single (or an industry-wide) labour union in the domestic country. We will discuss later on the implications of firm-specific labour unions in the domestic country under FDI by firm 1.

We assume that the inverse market demand is

$$
P=a-Q
$$

where $P$ is the price and $Q$ is the total output.

We consider the following game. At stage 1, firm 1 decides whether to export or to undertake FDI. At stage 2, the labour union in each country determines wage. At stage 3, the firms hire workers according to their requirement and compete like Cournot duopolists, and the profits are realised. We solve the game through backward induction.

To highlight the impact of labour union on the foreign firm's entry mode, we assume away trade cost (including transport cost and tariff) and any cost associated with FDI. It is then immediate from our structure that if the labour markets in both countries are perfectly competitive so that the equilibrium wages are the same in both countries, the foreign firm is indifferent between export and FDI. Hence, in our analysis, if the foreign firm prefers FDI compared to export, it is due to the presence of labour unions. 


\subsection{Export}

If the foreign firm decides to export at stage 1 , the marginal cost of production of firm 1 is $\lambda w_{1}^{x, d}$, while that of firm 2 is $w_{2}^{x, d}$, where $w_{1}^{x, d}$ and $w_{2}^{x, d}$ are determined by the labour unions in the foreign and the domestic countries respectively. The superscript $x, d$ denotes the situation that firm 1 serves the domestic market through export and the market structure is duopoly. Hence, firms 1 and 2 maximise the following expressions respectively to determine outputs:

$$
\pi_{1}^{x, d}=\left(a-q_{1}^{x, d}-q_{2}^{x, d}-\lambda w_{1}^{x, d}\right) q_{1}^{x, d} \text { and } \pi_{2}^{x, d}=\left(a-q_{1}^{x, d}-q_{2}^{x, d}-w_{2}^{x, d}\right) q_{2}^{x, d}
$$

where $q_{i}^{x, d}, i=1,2$, is the output of firm $i$. Standard calculations give the equilibrium outputs as:

$$
q_{1}^{x, d}=\frac{a-2 \lambda w_{1}^{x, d}+w_{2}^{x, d}}{3} \text { and } q_{2}^{x, d}=\frac{a+\lambda w_{1}^{x, d}-2 w_{2}^{x, d}}{3} .
$$

At stage 2, the labour unions in the foreign and the domestic countries determine their wages to maximise the following expressions respectively:

$$
\operatorname{Max}_{w_{1}^{x, d}} U_{1}^{x, d}=\operatorname{Max}_{w_{1}^{x, d}} w_{1}^{x, d}\left[\frac{\lambda\left(a-2 \lambda w_{1}^{x, d}+w_{2}^{x, d}\right)}{3}\right] \text { and } \operatorname{Max}_{w_{2}^{x, d}} U_{2}^{x, d}=\operatorname{Max}_{w_{2}^{x, d}} w_{2}^{x, d}\left(\frac{a+\lambda w_{1}^{x, d}-2 w_{2}^{x, d}}{3}\right) .
$$

The equilibrium wages are:

$$
w_{1}^{x, d}=\frac{a}{3 \lambda} \text { and } w_{2}^{x, d}=\frac{a}{3}
$$

It follows from (5) that the firms face the same labour productivity adjusted wage under export. This result is due to our assumption of zero reservation wages. This equality will breakdown if we consider a positive reservation wage. ${ }^{7}$ However, it is needless to say that our results, showing the incentive for FDI and the welfare implications, are not affected by the

\footnotetext{
${ }^{7}$ Mukherjee (2007) shows the implications of positive reservation wages in creating different productivity adjusted wages and different profits when the firms differ in labour productivities.
} 
simplified assumption of zero reservation wage, but a positive reservation wage makes the analytics unnecessarily complicated without providing any new insight.

Accordingly, the equilibrium outputs, profits and the union utilities are $q_{1}^{x, d}=\frac{2 a}{9}$, $q_{2}^{x, d}=\frac{2 a}{9}, \pi_{1}^{x, d}=\frac{4 a^{2}}{81}, \pi_{2}^{x, d}=\frac{4 a^{2}}{81}, U_{1}^{x, d}=\frac{2 a^{2}}{27}$ and $U_{2}^{x, d}=\frac{2 a^{2}}{27}$.

\subsection{FDI}

If the foreign firm undertakes FDI at stage 1, like many works on labour unions (Leahy and Montagna, 2000, Dhillon and Petrakis, 2002, Haucap and Wey, 2004, Manasakis and Petrakis, 2009, Mukherjee and Pennings, 2011 and Wang and Mukherjee, 2013), we assume that both firms hire workers in the domestic country from the same labour union charging a uniform wage. Institutional reasons may justify the uniform wage charged by the domestic labour union. ${ }^{8}$ As we will show below, our analysis itself may provide a justification for the domestic country's preference towards a uniform wage compared to discriminatory wages.

Since the firms differ in technologies, the labour union in the domestic country may set the uniform wage in a way so that both firms find production profitable or the labour union may set the uniform wage in a way so that only the foreign firm hires workers and produces like a monopolist. Hence, we need to internalise this strategic choice of the domestic labour union under FDI.

\footnotetext{
${ }^{8}$ Empirical evidences suggest that in many situations a labour union charges a uniform wage irrespective of the differences between the firms. For example, as discussed in Haucap et al. (2000 and 2001), a common feature of many labour markets in continental Europe is the "coverage extension rules", which implies that some or all employment terms are made generally binding for all industry participants and not only for the members of unions and employers' associations. 'In Germany, for example, collective wage agreements between a union and an employers' association can be made compulsory even for independent employers through so-called Allgemeinverbindlichkeitserkla"rung (AVE) . . . The Ministry of Labor can, on application of either unions or employers' associations, use an AVE to make some or all terms of a collectively negotiated employment contract generally binding for an entire industry, where otherwise only those unions, employers and employers' associations that have actually negotiated and signed the contract would be directly bound by it (§ 3 I TVG)" (Haucap et al. 2001). It is also noted in Haucap et al. (2001) that the number of AVEs almost continuously increased from 448 in 1975 to 588 in 1998.
} 


\subsubsection{Duopoly}

First, consider the situation where the domestic labour union sets the wage in a way so that both firms find production profitable. If the market structure is duopoly under FDI, the marginal cost of production for firm 1 is $\lambda w^{I, d}$, while that of firm 2 is $w^{I, d}$, where $w^{I, d}$ is the wage determined by the labour union in the domestic country. The superscript $I, d$ denotes the situation of duopoly market structure under FDI.

The profits of firms 1 and 2 are as follows:

$$
\pi_{1}^{I, d}=\left(a-q_{1}^{I, d}-q_{2}^{I, d}-\lambda w^{I, d}\right) q_{1}^{I, d} \text { and } \pi_{2}^{I, d}=\left(a-q_{1}^{I, d}-q_{2}^{I, d}-w^{I, d}\right) q_{2}^{I, d} .
$$

Standard calculations give the equilibrium outputs as:

$$
q_{1}^{I, d}=\frac{a+(1-2 \lambda) w^{I, d}}{3} \text { and } q_{2}^{I, d}=\frac{a-(2-\lambda) w^{I, d}}{3}
$$

The labour union in the domestic country faces the labour demand $\lambda q_{1}^{I, d}+q_{2}^{I, d}$, and maximises the following expression to determine $w^{I, d}$ :

$$
\begin{aligned}
\operatorname{Max}_{w^{I, d}} U_{2}^{I, d} & =\operatorname{Max}_{w^{l, d}} w^{I, d}\left[\frac{a-(2-\lambda) w^{I, d}}{3}+\frac{\lambda\left(a+(1-2 \lambda) w^{I, d}\right)}{3}\right] \\
& =\operatorname{Max}_{w^{I, d}} w^{I, d}\left[\frac{(1+\lambda) a-2\left(1-\lambda+\lambda^{2}\right) w^{I, d}}{3}\right] .
\end{aligned}
$$

The equilibrium wage is

$$
w^{I, d}=\frac{(1+\lambda) a}{4\left(1-\lambda+\lambda^{2}\right)}
$$

Accordingly, utility of the labour union in the domestic country is $U_{2}^{I, d}=\frac{[(1+\lambda) a]^{2}}{24\left(1-\lambda+\lambda^{2}\right)}$. 


\subsubsection{Monopoly}

It is clear from (7) that if the domestic labour union sets a wage under FDI that is not less than $\frac{a}{2-\lambda}$, the foreign firm will be a monopolist in the product market. In this situation, the foreign firm's marginal cost of production is $\lambda w^{I, m}$, where $w^{I, m}$ is the wage determined by the domestic labour union, and the superscript $I, m$ denotes the situation of monopoly under FDI.

Hence, firm 1 will maximise the following expression to determine its output:

$$
\pi_{1}^{I, m}=\left(a-q_{1}^{I, m}-\lambda w^{I, m}\right) q_{1}^{I, m}
$$

Standard calculations give the equilibrium output as:

$$
q_{1}^{I, m}=\frac{a-\lambda w^{I, m}}{2}
$$

If only firm 1 produces the product and demand workers from the labour union, the labour demand faced by the domestic labour union is $\lambda q_{1}^{I, m}$. The domestic labour union maximizes the following expression to determine $w^{I, m}$ :

$$
\operatorname{Max}_{w^{I, m}} U_{2}^{I, m}=\max _{w^{I, m}} w^{I, m}\left(\frac{\lambda a-\lambda^{2} w^{I, m}}{2}\right), \text { subject to } w^{I, m} \geq \frac{a}{2-\lambda} .
$$

The wage that maximises (12) is:

$$
w^{I, m}= \begin{cases}\frac{a}{2 \lambda}, & \text { for } 0<\lambda \leq \frac{2}{3} \\ \frac{a}{2-\lambda}, & \text { for } \frac{2}{3}<\lambda<1 .\end{cases}
$$

Accordingly, utility of the labour union in the domestic country is:

$$
U_{2}^{I, \mathrm{~m}}= \begin{cases}\frac{a^{2}}{8}, & \text { for } 0<\lambda \leq \frac{2}{3} \\ \frac{\lambda(1-\lambda) a^{2}}{(2-\lambda)^{2}}, & \text { for } \frac{2}{3}<\lambda<1 .\end{cases}
$$




\subsubsection{Monopoly or duopoly}

The expression (13) is derived under the assumption that the domestic labour union sets the wage in a way so that only firm 1 hires workers. However, it is yet to see when the domestic labour union actually wants to set the wage in this way.

By comparing $U_{2}^{I, \mathrm{~m}}$ with $U_{2}^{I, d}$, we have $U_{2}^{I, \mathrm{~m}}{ }_{1} U_{2}^{I, d}$ for $\lambda ¥ \frac{1}{2}$. This is shown in Figure 1 which plots the values of $U_{2}^{I, \mathrm{~m}}$ and $U_{2}^{I, d}$ in terms of $\lambda$ (with $a=1$ ).

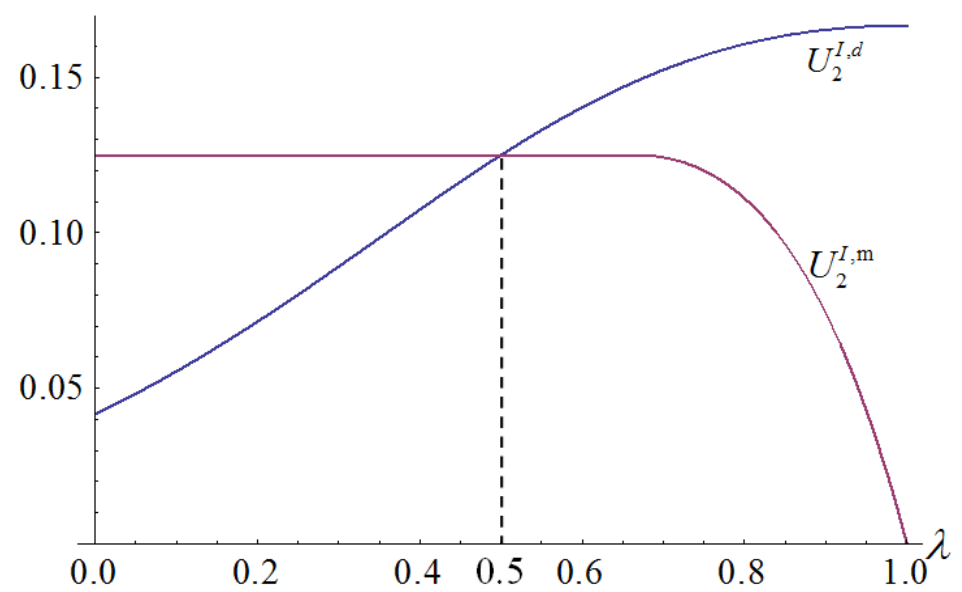

Figure 1. Comparison between $U_{2}^{I, \mathrm{~m}}$ and $U_{2}^{I, d}$ (with $a=1$ )

Hence, for $0<\lambda \leq \frac{1}{2}$, the domestic labour union sets the wage as $w^{I, m}=\frac{a}{2 \lambda}$, firm 1 produces like a monopolist in the product market, and the corresponding equilibrium values are $q_{1}^{I, m}=\frac{a}{4}, q_{2}^{I, m}=0, \pi_{1}^{I, m}=\frac{a^{2}}{16}, \pi_{2}^{I, m}=0$ and $U_{2}^{I, m}=\frac{a^{2}}{8}$.

For $\frac{1}{2}<\lambda<1$, the domestic labour union sets the wage as $w^{I, d}=\frac{(1+\lambda) a}{4\left(1-\lambda+\lambda^{2}\right)}$ so that both firms find it profitable to hire workers. The corresponding equilibrium values are 


$$
\begin{aligned}
& q_{1}^{I, d}=\frac{\left(5-5 \lambda+2 \lambda^{2}\right) a}{12\left(1-\lambda+\lambda^{2}\right)} \quad, \quad q_{2}^{I, d}=\frac{\left(2-5 \lambda+5 \lambda^{2}\right) a}{12\left(1-\lambda+\lambda^{2}\right)} \quad, \quad \pi_{1}^{I, d}=\left[\frac{\left(5-5 \lambda+2 \lambda^{2}\right) a}{12\left(1-\lambda+\lambda^{2}\right)}\right]^{2}, \\
& \pi_{2}^{I, d}=\left[\frac{\left(2-5 \lambda+5 \lambda^{2}\right) a}{12\left(1-\lambda+\lambda^{2}\right)}\right]^{2}, U_{1}^{I, d}=0 \text { and } U_{2}^{I, d}=\frac{[(1+\lambda) a]^{2}}{24\left(1-\lambda+\lambda^{2}\right)} .
\end{aligned}
$$

\subsection{FDI or export}

From the analysis in subsection 3.2, we know that the profit of firm 1 under FDI is $\pi_{1}^{I, m}=\frac{a^{2}}{16}$ for $0<\lambda \leq \frac{1}{2}$ and $\pi_{1}^{I, d}=\left[\frac{\left(5-5 \lambda+2 \lambda^{2}\right) a}{12\left(1-\lambda+\lambda^{2}\right)}\right]^{2}$ for $\frac{1}{2}<\lambda<1$. By comparing $\pi_{1}^{I}$ with $\pi_{1}^{x, d}$, we get $\pi_{1}^{I} \mid \pi_{1}^{x, d}$ for $\lambda ¥ \frac{\sqrt{105}-7}{4}$. This is shown in Figure 2 which plots the values of $\pi_{1}^{I}$ and $\pi_{1}^{x, d}$ in terms of $\lambda$ (with $a=1)$.

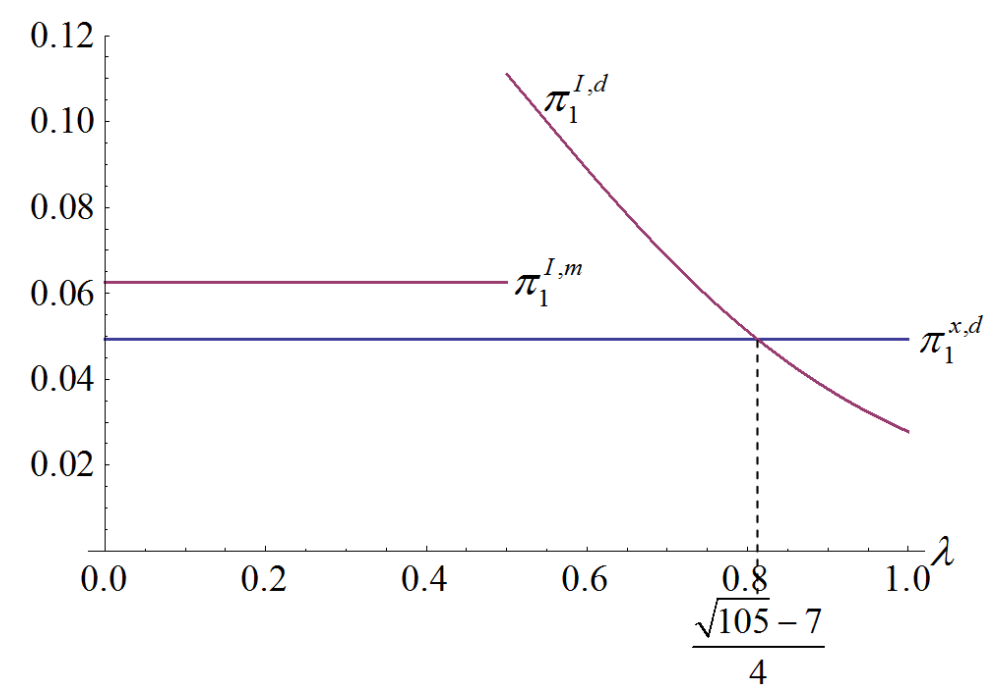

Figure 2. Comparison between $\pi_{1}^{I}$ and $\pi_{1}^{x, d}$ (with $a=1$ )

Hence, the following proposition is immediate. 
Proposition 1: If the labour markets in both countries are unionised, the foreign firm (i.e., firm 1) undertakes FDI (export) for $0<\lambda<\frac{\sqrt{105}-7}{4}\left(\frac{\sqrt{105}-7}{4} \leq \lambda<1\right)$. Under FDI, the domestic labour union sets the wage as $w^{I, m}=\frac{a}{2 \lambda}$ for $0<\lambda \leq \frac{1}{2}$, so as to make the foreign firm a monopolist, but it sets the wage as $w^{I, d}=\frac{(1+\lambda) a}{4\left(1-\lambda+\lambda^{2}\right)}$ for $\frac{1}{2}<\lambda<\frac{\sqrt{105}-7}{4}$, so that the firms compete like Cournot duopolists.

The intuition for the foreign firm's FDI decision shown in Proposition 1 will be clear once we look at the effects of FDI on wage. While FDI increases the wage faced by the domestic firm, it increases the wage faced by the foreign firm for $0<\lambda \leq \frac{1}{2}$ and $\frac{7-\sqrt{33}}{2}<\lambda<1$ but it decreases the wage faced by the foreign firm for $\frac{1}{2}<\lambda<\frac{7-\sqrt{33}}{2}$. The effects of FDI on the foreign firm's wage are shown in Figure 3. Moreover, FDI (compared to export) changes the market structure from duopoly to monopoly of the foreign firm for $0<\lambda \leq \frac{1}{2}$.

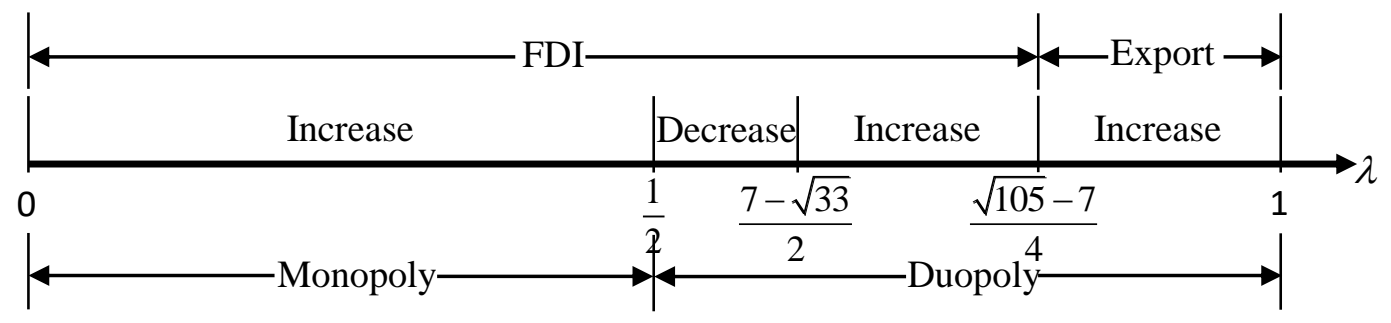

Figure 3. The effects of FDI on the foreign firm's wage, decision on FDI, and market structure 
If the foreign firm exports, the domestic union cares about the trade-off between higher wage against lower employment in the domestic firm but it does not internalise the effects on the foreign firm, viz., higher wage in the domestic country increase output and employment in the foreign firm. However, under FDI, the domestic union internalizes this effect, which increases domestic wage. $^{9}$

Under FDI, wage for the foreign firm increases due to the monopolisation effect (for $\lambda<\frac{1}{2}$ ) and the increase in labour demand in the domestic country (for $\frac{7-\sqrt{33}}{2}<\lambda<1$ ). However, if $\frac{1}{2}<\lambda<\frac{7-\sqrt{33}}{2}$, it does not create foreign monopoly but makes the labour demand significantly elastic to reduce wage for the foreign firm under FDI compared to export.

Since FDI decreases the foreign firm's wage but increases the domestic firm's wage for $\frac{1}{2}<\lambda<\frac{7-\sqrt{33}}{2}$, it is immediate that both the effects make the foreign firm better off under FDI compared to export.

However, the situations are different for $0<\lambda \leq \frac{1}{2}$ and $\frac{7-\sqrt{33}}{2}<\lambda<1$. If $0<\lambda \leq \frac{1}{2}$, FDI increases the foreign firm's wage but also creates a foreign monopoly by increasing the domestic firm's wage. The foreign firm's benefit from being a monopolist dominates its loss from a higher wage, thus creating the foreign firm's incentive for FDI in this situation.

FDI increases both firms' wages also for $\frac{7-\sqrt{33}}{2}<\lambda<1$, where both firms produce positive outputs. On one hand, higher wage in the foreign firm tends to reduce its profit by

\footnotetext{
${ }^{9}$ As shown in (8), under FDI, utility of the domestic union depends on employments in the domestic firm, $\frac{a-(2-\lambda) w^{I, d}}{3}$, and in the foreign firm, $\frac{\lambda\left(a+(1-2 \lambda) w^{I, d}\right)}{3}$. Hence, the domestic union internalises the effects of wage on employment in the foreign firm.
} 
reducing its cost efficiency, but on the other hand, higher wage in the domestic firm tends to increase the foreign firm's profit by reducing the domestic firm's cost efficiency. If the foreign firm is sufficiently more productive than the domestic firm (i.e., $\frac{7-\sqrt{33}}{2} \leq \lambda<\frac{\sqrt{105}-7}{4}$ ), implying that the labour coefficient is significantly lower in the foreign firm compared to the domestic firm, the wage cost is not significant for the foreign firm compared to the domestic firm. In this situation, the above-mentioned effect of a higher wage in the domestic firm dominates the effect of a higher wage in the foreign firm, which gives the foreign firm higher market share and higher profit under FDI compared to export. ${ }^{10}$ However, if $\frac{\sqrt{105}-7}{4}<\lambda<1$, the productivity of the foreign firm is not significantly higher than that of the domestic firm. In this situation, the effect of a higher wage in the foreign firm dominates the effect of a higher wage in the domestic firm, and the foreign firm's market share and profit are higher under export compared to FDI. It is worth noting that one would expect similar effects and results even if the demand curve is not linear.

To sum up, if the foreign firm is sufficiently technologically superior to that of the domestic firm (i.e. $0<\lambda<\frac{\sqrt{105}-7}{4}$ ), the foreign firm prefers FDI than export if there is a domestic industry-wide labour union charging a uniform wage. Since the foreign firm in our analysis has no incentive for FDI if the labour markets are perfectly competitive, Proposition 1 shows the foreign firm's rationale for undertaking FDI due to the presence of labour unions.

\footnotetext{
${ }^{10}$ It follows from our analysis that if both firms produce positive outputs under export and FDI, the foreign firm's profit under FDI will be higher than its profit under export if $\left(w^{I, d}-w_{2}^{x, d}\right)>2 \lambda\left(w^{I, d}-w_{1}^{x, d}\right)$ and this condition is more likely to happen with a lower $\lambda$.
} 


\subsection{The effects on the consumers, union utility and welfare}

It follows from Subsections 3.1 and 3.2 that $U_{1}^{I, d}<U_{1}^{x, d}, U_{1}^{I, m}<U_{1}^{x, d}, U_{2}^{x, d}<U_{2}^{I, d}$ for $\frac{1}{2}<\lambda<\frac{\sqrt{105}-7}{4}, U_{2}^{x, d}<U_{2}^{I, m}, \pi_{2}^{I, m}<\pi_{2}^{x, d}$ and $\pi_{2}^{I, d}<\pi_{2}^{x, d}$. The consumer surplus under export is $C S^{x, d}=\frac{8 a^{2}}{81}$, and it is greater than that of under FDI, which is $C S^{I, m}=\frac{a^{2}}{32}$ for $0<\lambda \leq \frac{1}{2}$ and $C S^{I, d}=\frac{\left(7-10 \lambda+7 \lambda^{2}\right)^{2} a^{2}}{288\left(1-\lambda+\lambda^{2}\right)^{2}}$ for $\frac{1}{2}<\lambda<\frac{\sqrt{105}-7}{4}$

Hence, the following proposition is immediate.

Proposition 2: If the labour markets in both countries are unionised, FDI benefits the domestic labour union, but it makes the foreign labour union, the domestic firm and the consumers worse off.

Higher domestic labour demand under FDI compared to export is the reason for the favourable effect of FDI on the domestic labour union, while higher domestic unionised wage is responsible for the adverse effect of FDI on the domestic firm's profit.

The reasons for the adverse effect of FDI on the consumers are as follows. FDI not only increases the foreign firm's marginal cost of production but also creates a foreign monopoly for $0<\lambda \leq \frac{1}{2}$, thus reducing the consumer surplus under FDI compared to export in this situation.

If both firms produce positive outputs, the total outputs of the firms depend negatively on the sum of the firms' marginal costs of production. Since FDI (compared to export) increases the sum of the firms' marginal costs of production for $\frac{1}{2}<\lambda<\frac{\sqrt{105}-7}{4}$, it decreases the consumer surplus compared to export. 
It follows from Subsections 3.1 and 3.2 that domestic welfare, which is the sum of consumer surplus, domestic firm's profit and the utility of domestic labour union, is $W_{2}^{x, d}=\frac{2 a^{2}}{9}$ under export, while, under FDI, it is $W_{2}^{I, m}=\frac{5 a^{2}}{32}$ for $0<\lambda \leq \frac{1}{2}$ and $W_{2}^{I, d}=\frac{\left(23-56 \lambda+96 \lambda^{2}-76 \lambda^{3}+37 \lambda^{4}\right) a^{2}}{96\left(1-\lambda+\lambda^{2}\right)^{2}}$ for $\frac{1}{2}<\lambda<\frac{\sqrt{105}-7}{4}$. We get that $W_{2}^{I, m}<W_{2}^{x, d}$, $W_{2}^{I, d}<W_{2}^{x, d}$ for $\frac{1}{2}<\lambda<\bar{\lambda}$ and $W_{2}^{x, d} \leq W_{2}^{I, d}$ for $\bar{\lambda} \leq \lambda<\frac{\sqrt{105}-7}{4}$, where $\bar{\lambda}(\approx 0.593344)$ is a solution of the equation $5-40 \lambda+96 \lambda^{2}-100 \lambda^{3}+47 \lambda^{4}=0$. Hence, the adverse effects of FDI on the consumers and the domestic firm are higher (lower) than the favourable effect of FDI on the domestic labour union for $0<\lambda<\bar{\lambda}\left(\bar{\lambda}<\lambda<\frac{\sqrt{105}-7}{4}\right)$.

The foreign country's welfare is the sum of foreign firm's profit and utility of the foreign labour union. Welfare of the foreign country under export is $W_{1}^{x, d}=\frac{10 a^{2}}{81}$, and it is greater than that of under FDI, which is $W_{1}^{I, m}=\frac{a^{2}}{16}$ for $0<\lambda \leq \frac{1}{2}$ and $W_{1}^{I, d}=\left[\frac{\left(5-5 \lambda+2 \lambda^{2}\right) a}{12\left(1-\lambda+\lambda^{2}\right)}\right]^{2}$ for $\frac{1}{2}<\lambda<\frac{\sqrt{105}-7}{4}$. Although FDI makes the foreign firm better off compared to export, the loss of foreign union's utility under FDI is higher than the foreign firm's benefit from FDI, thus reducing foreign welfare under FDI compared to export.

The following proposition summarises the above discussion. 
Proposition 3: If the labour markets in both countries are unionised, FDI decreases (increases) domestic welfare for $0<\lambda<\bar{\lambda}\left(\bar{\lambda}<\lambda<\frac{\sqrt{105}-7}{4}\right)$, while it always decreases foreign welfare compared to export.

\subsection{Wage discrimination under FDI}

Like several existing works on FDI in unionised labour markets (Leahy and Montagna, 2000, Dhillon and Petrakis, 2002, Haucap and Wey, 2004, Manasakis and Petrakis, 2009, Mukherjee and Pennings, 2011 and Wang and Mukherjee, 2013), we assume that the domestic labour union charges a uniform wage under FDI. As mentioned already, institutional reasons may justify the uniform wage charged by the domestic labour union. If the labour union charges a uniform wage under FDI, we have seen that FDI imposes higher burden on the less productive domestic firm compared to the more productive foreign firm, thus creating the raising rival's cost effect and may induce the foreign firm to undertake FDI.

If the institutional factors do not prevent the domestic labour union from charging a uniform wage, ex-post FDI, the domestic labour union would prefer to charge discriminatory wages compared to a uniform wage. If the domestic labour union can charge discriminatory wages under FDI, the raising rival's cost effect does not arise and there is no incentive for FDI. If the domestic labour union charges discriminatory wages under FDI, the equilibrium wages charged to firms 1 and 2 are respectively $\boldsymbol{\omega}_{1}^{\mathbf{l}}=\frac{a}{2 \lambda}$ and $\mathbb{W}_{2}=\frac{a}{2}$, and the equilibrium profit of firm 1 is $\boldsymbol{t}_{1}^{\mathbf{U}}=\frac{a^{2}}{36}$, which is lower than firm 1's equilibrium profit under export. Hence, firm 1 does not undertake FDI in our analysis if the domestic labour union charges discriminatory wages under FDI. 
It is clear from the equilibrium discriminatory wages under FDI that the firms face the same marginal costs ( $\lambda w_{1}$ for firm 1 and $w_{2}$ for firm 2 ), since the firms face the same labour productivity adjusted wage. Similarly, the firms pay the same labour productivity adjusted wage under export by firm 1 . However, since the labour productivity adjusted wages are higher under FDI than under export, firm 1 does not have the incentive for FDI under discriminatory wages.

It is immediate from the above discussion that if the domestic labour union can charge discriminatory wages under FDI, firm 1's equilibrium strategy would be to export to the domestic country. On the other hand, if the domestic labour union is compelled to charge a uniform wage under FDI, firm 1 may undertake FDI, which may increase domestic welfare compared to export. Hence, in the absence of any institutional factors, our results themselves may justify the domestic country's preference for a uniform unionised wage compared to discriminatory unionised wages.

The following proposition follows from the above discussion.

Proposition 4: If the labour markets in both countries are unionised, in our analysis, the domestic country prefers a uniform wage compared to discriminatory wages charged by the industry-wide domestic labour union if $\bar{\lambda}<\lambda<\frac{\sqrt{105}-7}{4}$.

Proposition 4 along with Propositions 1 and 3 suggests that if no other institutional factors outside our model induce the domestic labour union to charge a uniform wage, in our analysis, the domestic government will ask the industry-wide domestic labour union to charge a uniform wage if $\bar{\lambda}<\lambda<\frac{\sqrt{105}-7}{4}$, which, in turn, will attract FDI and will increase 
domestic welfare compared to export. Hence, the FDI inducing role of the unionised markets remains even with this endogenous choice of the domestic country for uniform or discriminatory wages. However, in this situation, FDI will increase domestic welfare compared to export. For other values of $\lambda$, the domestic country would prefer discriminatory wages to a uniform wage charged by the industry-wide labour union in the domestic country.

\subsection{Firm-specific labour unions under FDI}

We have assumed so far that if firm 1 undertakes FDI, both firms hire workers from an industry-wide labour union in the domestic country. Now we want to see the implications of firm-specific labour unions in the domestic country under FDI by firm 1.

If firm 1 undertakes FDI and firms 1 and 2 hire workers from the firm-specific labour unions in the domestic country, the equilibrium outcomes under FDI will be similar to the equilibrium outcomes shown in Subsection 3.1, since we have assumed no transportation costs for exporting and the same reservation wages in both countries. This indicates that if there are firm-specific domestic labour unions under FDI, firm 1 is indifferent between export and FDI in our analysis. However, we have shown in Proposition 1 that firm 1 may prefer FDI compared to export if there is an industry-wide domestic labour union under FDI, and Proposition 3 shows that FDI by firm 1 may increase domestic welfare compared to export.

The following proposition is then immediate from the above discussion and Propositions 1 and 3 .

Proposition 5: If the labour markets in both countries are unionised and $0<\lambda<\frac{\sqrt{105}-7}{4}$, an industry-wide domestic labour union with a uniform wage setting behaviour is preferable compared to firm-specific domestic labour unions for attracting FDI and making the domestic 
labour union better off. An industry-wide domestic labour union with a uniform wage setting behaviour is also preferable compared to firm-specific domestic labour unions for domestic welfare if $\bar{\lambda}<\lambda<\frac{\sqrt{105}-7}{4}$.

The preference for an industry-wide union compared to firm-specific unions when the firms compete in the host-country market, as shown in Proposition 5, is in contrast to the existing literature (Leahy and Montagna, 2000) and follows easily from our assumptions of no international transportation costs and no difference in the reservation wages, which we assume deliberately to show the FDI inducing effects of labour union. Since the equilibrium outcomes would be continuous in transportation costs and the difference in the reservation wages, our qualitative results would definitely hold if the international transportation costs and the difference in the reservation wages are positive but small.

\section{Conclusion}

The existing theoretical literature showed that the factors such as trade cost saving, lower cost of production, information asymmetry, exchange rate uncertainty and environmental regulation create the rationale for undertaking FDI. However, the effects of the labour market are underexplored. While the empirical evidence on the relationship between labour union and FDI is mixed, the theoretical literature mainly explains that the presence of labour union reduces the incentive for FDI. We provide an explanation for the positive relationship between labour union and FDI, thus providing a new rationale for undertaking FDI.

We show that the raising rival's cost motive may create the incentive for FDI in industries with unionised labour markets. If the labour markets are unionised, a multinational firm may 
prefer FDI to export if the foreign multinational firm is sufficiently technologically superior to that of its domestic counterpart.

Our analysis also provides striking implications on the consumer and social welfare. FDI (compared to export) reduces the consumer surplus and foreign welfare, and it reduces domestic welfare if the multinational firm is sufficiently technologically superior to the domestic firm. FDI also makes the domestic firm and the foreign labour union worse off but it makes the domestic labour union better off compared to export.

We further show that an industry-wide domestic labour union charging a uniform wage may create higher incentive for FDI and higher domestic welfare compared to both the industrywide domestic labour union charging discriminatory wages and firm-specific domestic labour unions.

In this paper, we consider green-field FDI and show the effects of labour unions on the incentive for FDI. There is a literature showing the effects of other types of foreign direct investments, such as cross-border mergers and joint ventures, on wages and employments (Lommerud et al., 2005 and 2006, Belderbos and Zou, 2007 and Clougherty et al., 2014). A natural extension of this paper will be to consider the effects of labour unions in the presence of different types of foreign direct investment, such as green-field investment and crossborder mergers. 


\section{References}

Aray, H. and J. Gardeazabal, 2010, 'Going multinational under exchange rate uncertainty', Journal of International Money and Finance, 29: 1171-1191.

Bagwell K. and R. B. Staiger, 2003, 'Informational aspects of foreign direct investment and the multinational firm', Japan and the World Economy, 15: 1-20.

Belderbos, R. and J. Zou, 2007, 'On the growth of foreign affiliates: multinational plant networks, joint ventures, and flexibility', Journal of International Business Studies, 38: $1095-1112$.

Brainard, S. L., 1997, 'An empirical assessment of the proximity-concentration tradeoff between multinational sales and trade', American Economic Review, 87: 520-544.

Bughin, J. and S. Vannini, 1995, 'Strategic direct investment under unionized oligopoly', International Journal of Industrial Organization, 13: 127-145.

Clougherty, J.A., K. Gugler, L. Sørgard and F.W. Szücs, 2014, 'Cross-border mergers and domestic-firm wages: Integrating "spillover effects" and "bargaining effects", Journal of International Business Studies, 45: 450-470.

Coughlin, C., J. Terza and V. Arromdee, 1991, 'State characteristics and the location of foreign direct investment within the United States', Review of Economics and Statistics, 73: 675-682.

Cooke, W.N., 1997, 'The influence of industrial relations factors on U.S. foreign direct investment abroad', Industrial and Labor Relations Review, 51: 3-17.

Cooke, W.N. and D.S. Noble, 1998, 'Industrial relations systems and US foreign direct Investment Abroad', British Journal of Industrial Relations, 36: 581-609.

Dijkstra, B., A. J. Mathew and A. Mukherjee, 2011, 'Environmental regulation: an incentive for foreign direct investment', Review of International Economics, 19: 568-578. 
Dhillon, A. and E. Petrakis, 2002, 'A generalised wage rigidity result', International Journal of Industrial Organization, 20: 285-311.

Friedman, J., D.A. Gerlowski and J. Silberman, 1992, 'What attracts foreign multinational corporations? evidence from branch plant location in the United States', Journal of Regional Science, 32: 403-418.

Fumagalli, C., 2003, 'On the welfare effects of competition for foreign direct investments', European Economic Review, 47: 963-983.

Galan, J.I., J.G.Benito and J.A. Zuñiga-Vincente, 2007, 'Factors determining the location decisions of Spanish MNEs: an analysis based on the investment development path', Journal of International Business Studies, 38: 975-997.

Haucap, J. and C. Wey, 2004, 'Unionisation structures and innovation incentives', Economic Journal, 114: C149-165.

Haucap, J., U. Pauly and C. Wey, 2000, 'The incentives of employers' associations to raise rivals' costs in the presence of collective bargaining', in P. de Gijsel, R. Olthoff R and T. Zwick (Eds.), The unemployment debate: current issues, pp 185-226. Metropolis Verlag, Marburg.

Haucap, J., U. Pauly and C. Wey, 2001, 'Collective wage setting when wages are generally binding: an antitrust perspective', International Review of Law and Economics, 21: 287307.

Haufler, A. and F. Mittermaier, 2011, 'Unionisation triggers tax incentives to attract foreign direct investment', Economic Journal, 121: 793-818.

Head, K. and J. Ries, 2003, 'Heterogeneity and the FDI versus export decision of Japanese manufacturers', Journal of the Japanese and International Economies, 17: 448-467.

Helpman, E., M. J. Melitz and S. R. Yeaple, 2004, 'Export versus FDI with heterogeneous firms', The American Economic Review, 94: 300-316. 
Horstmann, I. J. and J. R. Markusen, 1987, 'Licensing versus direct investment: a model of internalization by the multinational enterprise', Canadian Journal of Economics, 20: 464481.

Horstmann, I. J. and J. R. Markusen, 1996, 'Exploring new markets: direct investments, contractual relations and the multinational enterprise', International Economic Review, 37: $1-19$.

Layard, R., S. Nickell and R. Jackman, 1991, Unemployment, macroeconomic performance and the labour market, Oxford University Press, Oxford.

Leahy, D. and C. Montagna, 2000, 'Unionisation and foreign direct investment: challenging conventional wisdom?', Economic Journal, 110: 80-92.

Lommerud, K. E., F. Meland and L. Sørgard, 2003, 'Unionised oligopoly, trade liberalisation and location choice', Economic Journal, 113: 782-800.

Lommerud, K.E., O.D. Straume and L. Sørgard, 2005, 'Downstream merger with upstream market power', European Economic Review, 49: 717-743.

Lommerud, K. E., O.D. Straume and L. Sørgard, 2006, 'National versus international mergers in unionized oligopoly', RAND Journal of Economics, 37: 212-233.

Manasakis, C. and E. Petrakis, 2009, 'Union structure and firms' incentives for cooperative R\&D investments', Canadian Journal of Economics, 42: 656-693.

Markusen, J., 1998, 'Multinational firms, location and trade', World Economy, 21: 733-756.

Moner-Colonques, R., V. Orts and J. J. Sempere-Monerris, 2008, 'Entry in foreign markets under asymmetric information and demand Uncertainty', Southern Economic Journal, 74: $1105-1122$.

Mukherjee, A., 2007, 'Irrelevance of productivity difference: a case with labor union', Economics Bulletin, 10(17): 1-8. 
Mukherjee, A., 2008, 'Unionised labour market and strategic production decision of a multinational', Economic Journal, 118: 1621-1639.

Mukherjee, A. and E. Pennings, 2011, 'Unionization structure, licensing and innovation', International Journal of Industrial Organization, 29: 232-241.

Mukherjee, A. and K. Suetrong, 2012, 'Unionisation Structure and Outward Foreign Direct Investment', Journal of Institutional and Theoretical Economics, 168: 266-279.

Naylor, R., 2003, 'Economic Models of Trade Union Behaviour', in J.T. Addison and C. Schnabel (eds.), International Handbook of Trade Unions, Cheltenham, Edward Elgar.

Naylor, R. and M. Santoni, 2003, 'Foreign direct investment and wage bargaining', Journal of International Trade and Economic Development, 12: 1-18.

Neary, J. P. and D. Leahy, 2000, 'Strategic trade and industrial policy towards dynamic oligopolies', Economic Journal, 110: 484-504.

Saggi, K., 2002, 'Trade, foreign direct investment, and international technology transfer: A survey', World Bank Research Observer, 17: 191-235.

Salop, S. C. and D. T. Scheffman, 1983, 'Raising rivals' cost: recent advances in the theory of industrial structure', American Economic Review, 73: 267-271.

Salop, S. C. and D. T. Scheffman, 1987, 'Cost-raising strategies', Journal of Industrial Economics, $36: 19-34$.

Staiger, R. and G. Tabellini, 1987, 'Discretionary trade policy and excessive protection', American Economic Review, 77: 823-837.

Traxler, F. and B. Woitech, 2000, 'Transnational investment and national labour market regimes: a case of 'regime shopping'?', European Journal of Industrial Relations, 6: 141159.

UNCTAD, 2006, World Investment Report: FDI from developing and transition economies: implications for development, United Nations, New York and Geneva. 
Vannini, S., and J. Bughin, 2000, 'To be (unionized) or not to be? A case for cost-raising strategies under Cournot oligopoly’, European Economic Review, 44: 1763-1781.

Wang, L. F. S. and A. Mukherjee, 2013, 'Labour union, entry and consumer welfare', Economics Letters, 120, 603-605.

Yoshida, Y., 2000, 'Third-degree price discrimination in input markets: output and welfare', American Economic Review, 90: 240-246.

Zhao, L., 1995, 'Cross-hauling direct foreign investment and unionised oligopoly', European Economic Review, 39: 1237-1253. 